\title{
Prevalence of Group C Streptococcus and Fusobacterium Necrophorum in Patients With Sore Throat: A Meta-Analysis
}

\author{
Christian Marchello, MS, \\ MT(ASCP) \\ Mark H. Ebell, MD, MS
}

Department of Epidemiology and Biostatistics, College of Public Health, University of Georgia, Athens, Georgia

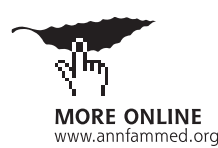

Conflicts of interest: authors report none.

\section{CORRESPONDING AUTHOR}

Mark H. Ebell, MD, MS

125 Miller Hall

UGA Health Sciences Campus

Athens, GA 30602

ebell@uga.edu

\begin{abstract}
PURPOSE The prevalence of Group C beta-hemolytic streptococcus and Fusobacterium necrophorum among patients with sore throat in the outpatient setting has not been previously summarized. We set out to derive prevalence information from the existing literature.
\end{abstract}

METHODS We performed a systematic review of MEDLINE for studies reporting the prevalence of $F$ necrophorum or Group C streptococcus or both in prospective, consecutive series of outpatients with sore throat, as well as laboratory-based studies of throat cultures submitted from primary care. We limited searches to studies where the majority of data was collected after January 1, 2000, to reflect contemporary microbiological methods and prevalences. Each author independently reviewed the articles for inclusion and abstraction of data; we resolved discrepancies by consensus discussion. We then performed a meta-analysis to calculate the pooled prevalence estimates using a random effects model of raw proportions.

RESULTS A total of 16 studies met our inclusion criteria. The overall prevalences of Group C streptococcus and $F$ necrophorum were 6.1\% (95\% Cl, 3.2\%-9.0\%) and $18.9 \%$ (95\% Cl, 10.5\%-27.2\%), respectively. When stratified by study type, the prevalences of Group $($ streptococcus and $F$ necrophorum in laboratory-based studies were $6.6 \%(95 \% \mathrm{Cl},-1.0 \%$ to $14.2 \%)$ and $18.8 \%(95 \% \mathrm{Cl}, 6.5 \%-31.1 \%)$, respectively. In primary care patients with sore throat, Group C streptococcus had a prevalence of $6.1 \%(95 \% \mathrm{Cl}, 3.1 \%-9.2 \%)$, while $\mathrm{F}$ necrophorum had a prevalence of $19.4 \%$ (95\% Cl, $14.7 \%-24.1 \%)$.

CONCLUSIONS Group C streptococcus and Fusobacterium necrophorum are commonly detected in patients with acute pharyngitis. Research is needed, however, to determine whether these bacteria are truly pathogenic in patients with pharyngitis and whether antibiotics reduce the duration of symptoms or the likelihood of complications.

Ann Fam Med 2016;14:567-574. doi: 10.1370/afm.2005.

\section{INTRODUCTION}

$\mathrm{P}$ haryngitis is an important cause of morbidity, and was responsible for $1.4 \%$ of all visits ${ }^{1}$ to ambulatory care physicians in 2012, making it the 10th most common reason for such visits. While most cases of pharyngitis are viral, Group A beta-hemolytic streptococci are responsible for approximately $10 \%$ of episodes in adults and up to $30 \%$ in children. ${ }^{2}$ Recently, it has been suggested that 2 other bacteria may be important causes of pharyngitis, but their prevalence has not been well described.

The first, Group C beta-hemolytic streptococcus, is often found in patients with acute pharyngitis. While it is traditionally not thought to be a pathogen, recent studies have found that it appears to cause symptoms similar to those caused by Group A streptococcus. ${ }^{3,4}$ For example, in a study of 606 adults in primary care who had sore throat, those with Group C or $\mathrm{G}$ streptococcal infection resembled those with Group A streptococcus in rapidity of onset, likelihood of adenopathy, intensity of pharyngeal inflammation, and likelihood of purulence. ${ }^{5}$ In addition, Group C streptococcus appears to share some of the virulence factors found in Group A. ${ }^{6}$ While 
it is not known to cause rheumatic fever, identification and treatment may reduce the duration of symptoms and the period of communicability of the infection.

The second organism, Fusobacterium necrophorum, is a known cause of serious complications of acute pharyngitis and is associated with recurrent sore throat, persistent sore throat syndrome, peritonsillar abscess, and Lemierre's syndrome. ${ }^{7}$ The latter is characterized by unilateral neck swelling due to suppurative thrombophlebitis of the internal jugular vein and may lead to sepsis, pulmonary abscess, and death. ${ }^{8}$

The prevalence of both of these pathogens, particularly in outpatient primary care, is not well known and has not been previously summarized. Therefore, we performed a meta-analysis to describe the prevalence of Group C streptococcus and Fusobacterium necrophorum among patients with sore throat in primary care.

\section{METHODS}

\section{Inclusion and Exclusion Criteria}

We included 2 types of studies: those that reported the prevalence of $F$ necrophorum or Group $C$ streptococcus in prospective, consecutive series of outpatients presenting with sore throat or clinically diagnosed pharyngitis, and laboratory-based studies that reported the prevalence of F necrophorum or Group C streptococcus in throat cultures submitted entirely or largely from outpatient or primary care (presumably for sore throat or clinically diagnosed pharyngitis). We report results separately for these groups, since laboratory-based studies may reflect a more highly selected group of patients with persistent, ambiguous, or severe symptoms. Acceptable reference standards included culture and polymerase chain reaction (PCR). In order to reflect contemporary microbiology and prevalences, we limited searches to studies where the majority of data was collected after January 1, 2000. We also limited our search to studies set in high-income countries that are also members of the Organisation for Economic Cooperation and Development (OECD) ${ }^{9}$ (Supplemental Appendix A, http:// www.annfammed.org/content/14/6/567/suppl/DC1). We defined outpatient care as including patients presenting to a primary care physician, an urgent care clinic, or an emergency department.

We excluded studies without an abstract; studies that included only or predominantly immunocompromised patients; studies that included predominantly patients with hospital-acquired or recurrent tonsillitis, peritonsillar abscess, or invasive streptococcal disease; and studies of special or unusual populations. We also excluded casecontrol studies, case reports, case series, retrospective studies, outbreak investigations, and studies that did not use throat culture or PCR as a reference standard test.

\section{Search Strategy}

For Group C streptococcus, we conducted a systematic review of MEDLINE using 2 search strategies. The first focused on the prevalence, incidence, and epidemiology of Group C streptococcus among patients with pharyngitis in outpatient care and was limited to studies in English or German. Because this search identified only 42 abstracts, we performed a second search on the differential diagnosis of pharyngitis without language limits, resulting in a total of 202 abstracts for Group C streptococcus. For $F$ necrophorum, we performed a search similar to the initial search for Group C streptococcus but included complications such as peritonsillar abscess and Lemierre's syndrome. This returned only 79 abstracts, so again we used a secondary search that excluded peritonsillar abscess and Lemierre's syndrome but added pharyngitis. The $F$ necrophorum search strategies returned a total of 191 abstracts. Appendix B includes detailed search terms used for each strategy (Supplemental Appendix B, http://www.annfammed.org/content/14/6/567/suppl/ DC1). We also searched the first 200 studies identified by MEDLINE as related to a highly relevant publication by Amess and colleagues in $2007,{ }^{10}$ as well as the reference lists of included studies and of any review articles that were identified. We reran the searches in December, 2015, just before we wrote the manuscript.

\section{Data Abstraction}

Both investigators reviewed abstracts for each search in tandem, and both reviewed in full studies that seemed likely to meet our inclusion criteria. For each included study, we both abstracted study characteristics and data regarding prevalence, resolving any discrepancies by consensus discussion. Results were stored in a series of Google Drive spreadsheets and imported into the statistics package for analysis.

\section{Study Quality}

There are no widely accepted standard instruments for evaluating the quality of studies of prevalence like those used in meta-analyses of diagnosis or therapy studies. ${ }^{11,12}$ Characteristics that we felt were important to ensure generalizability were built into our inclusion and exclusion criteria to assure a uniformly high level of quality for the included studies. Specifically, for studies of outpatients with sore throat or pharyngitis, we included only studies of consecutive, prospective samples of patients. We excluded case-control and retrospective clinical studies. For laboratory-based studies, we included only those reporting on a consecutive series of all submitted throat swabs or a random sample of throat swabs from a defined period. Finally, we included only studies with a high quality, valid reference standard (PCR or culture). 


\section{Analysis}

Pooled prevalence estimates were calculated with random effects model of raw proportions. The double arcsine transformation has been recommended for the meta-analysis of prevalence, ${ }^{13}$ but we found that pooled estimates do not vary significantly following transformation. Therefore, we used raw proportions for clarity and understanding of true prevalence numbers. Statistical analysis was performed in $\mathrm{R}$, version 3.2.2, including plots of prevalences for each infection using the metafor procedure. We quantified heterogeneity using the $\mathrm{I}^{2}$ statistic, which represents the proportion of total variance that is due to between-study rather than within-study variability. ${ }^{14}$ It is important to note that $\mathrm{I}^{2}$ is of limited value and may give exaggerated estimates of heterogeneity when there are a small number of studies, as in our analysis. ${ }^{15}$

\section{RESULTS}

Our initial search of the literature returned 404 articles for Group C streptococcus and 391 for F necrophorum. After review of the abstracts, we reviewed 21 articles for Group C streptococcus and 26 for $F$ necrophorum in detail. Review of the reference lists identified an additional 16 studies for Group $C$ streptococcus and 2 for $F$ necrophorum that we reviewed in full. In the end, a total of 14 studies from these 2 searches met our inclusion criteria. ${ }^{4,5,10,16}$ ${ }^{17-26}$ An updated search made just before we wrote the manuscript identified 2 additional studies ${ }^{7}, 27$ for a final count of 16 included studies (Figure 1). Table 1 summarizes the study characteristics: 6 reported the prevalence of Group C streptococcus, ${ }^{4,5,17-20} 3$ the prevalence of $F$ necrophorum, ${ }^{16,21,22}$ and 7 the prevalence of both pathogens. ${ }^{7,10,}{ }^{23-27}$ Data collection ranged from 2000 to 2014 and took place in 9 countries.

The prevalence of Group C streptococcus is summarized in the forest plot in Figure 2. The overall prevalence of Group C streptococcus was 6.1\% (95\% CI, $3.2 \%-9.0 \%$ ) with a range from $0.5 \%{ }^{14}$ to $24.8 \% .^{10}$

As mentioned above, we stratified studies into 2 types: studies of outpatients with sore throat and laboratory-based studies that reported the results of any throat swabs sent to a participating laboratory. The prevalence of Group C streptococcus was similar in the two groups of studies $(6.1 \%, 95 \% \mathrm{CI}, 3.1 \%-9.2 \%$ in outpatients with sore throat and $6.6 \%, 95 \% \mathrm{CI},-1.0 \%$ to $14.2 \%$ in laboratory studies). There was significant heterogeneity, with an $\mathrm{I}^{2}$ statistic of $98 \%$ for all studies. As we said above, though, heterogeneity may be inflated when the number of studies is small, ${ }_{1}^{15}$ and 8 of 13 studies of Group C streptococcus reported a prevalence between $0.5 \%$ and $5.0 \%$, while only 2 studies reported a prevalence greater than $10 \%$. Heteroge- neity for Group C streptococcus prevalence calculated separately for outpatient studies was $94 \%$ and for laboratory-based studies was $98 \%$, although dropping an outlier with a prevalence of $25 \%{ }^{25}$ lowered the heterogeneity to $68 \%$ for laboratory-based studies.

Figure 3 shows a forest plot summarizing the prevalence of $F$ necrophorum. The overall prevalence was $18.9 \%$ (95\% CI $10.5 \%-27.2 \%)$. Again, the forest plot is stratified by study type: studies of outpatients with sore throat and laboratory-based studies reporting on throat swabs sent to a participating laboratory. F necrophorum prevalence ranged widely in the studies, from $4.9 \%{ }^{10}$ to $51.4 \% .{ }^{25}$ Stratified by setting, the summary estimate of prevalence was $18.8 \%(95 \% \mathrm{CI}, 6.5 \%-31.1 \%)$ in laboratory-based studies and $19.4 \%$ (95\% CI, 14.7\%-24.1\%) in outpatient studies. Again, there was a large amount of heterogeneity, with an overall $\mathrm{I}^{2}$ statistic of $99 \%$. Visual inspection of the forest plot confirmed significant heterogeneity for studies of $F$ necrophorum, especially among the laboratorybased studies. Considered separately, the outpatient studies had an $\mathrm{I}^{2}$ of $62 \%$, although this may be inflated by the small number of studies, and all of the Cls overlapped.

Four studies included primarily patients from what may be described as a late adolescent and young adult or "college age" populations. They found prevalences of Group C streptococcus of $6.4 \%{ }^{21}$ and $24.8 \%,{ }^{25}$ and prevalences of $F$ necrophorum of $20.5 \%,{ }^{7} 22.2 \%,{ }^{22} 23.4 \%,{ }^{21}$ and $51.4 \% .{ }^{25}$ In each case, the prevalence of the pathogen was higher than the overall mean prevalence, consistent with previous observations that these pathogens are more common in young adult populations. ${ }^{7}$

\section{DISCUSSION}

In patients with acute pharyngitis or tonsillitis, Group $\mathrm{C}$ streptococcus and $F$ necrophorum are both relatively common. Whether this is clinically important remains to be determined; it depends on whether they are merely colonizing the pharynx or are pathogens. One study compared the bacteria and viruses detected in throat cultures from 220 patients with acute pharyngotonsillitis with those found in 128 asymptomatic controls. They found higher percentages of patients with Group C streptococcus (3.6\% vs $0.8 \%, P=.16)$ and $F$ necrophorum ( $15.0 \%$ vs $3.1 \%, P=.001)$ in the symptomatic patients, ratios similar to those for Group A streptococcus (30\% vs $2.3 \%, P<.001)$ and rhinovirus $(6.4 \%$ vs $2.3 \%, P=.09) .{ }^{27}$ Another found $F$ necrophorum in 14 of 85 university students with sore throat (16.5\%), compared with 29 of 326 who were asymptomatic (8.9\%). ${ }^{21}$ Most recently, Centor and colleagues found higher rates of both $F$ necrophorum (20.5\% vs 9.4\%) and Group C streptococcus (9.0\% vs $3.9 \%$ ) in university students with sore throat than in asymptomatic controls. ${ }^{7}$ Little and colleagues argue 
that Group C streptococcus is a likely pathogen because it has the same virulence factors as Group A streptococcus (streptokinase, $\mathrm{M}$ proteins, peptidase, and a hyaluronic capsule), can cause septicemia, and is associated with signs and symptoms similar to those of Group A streptococcus. ${ }^{5}$ F necrophorum is clearly a pathogen in rare patients with Lemierre's syndrome and is often found in patients with peritonsillar abscess, but based on our findings may

\section{Figure 1. Process used to identify articles from initial search to final decision}

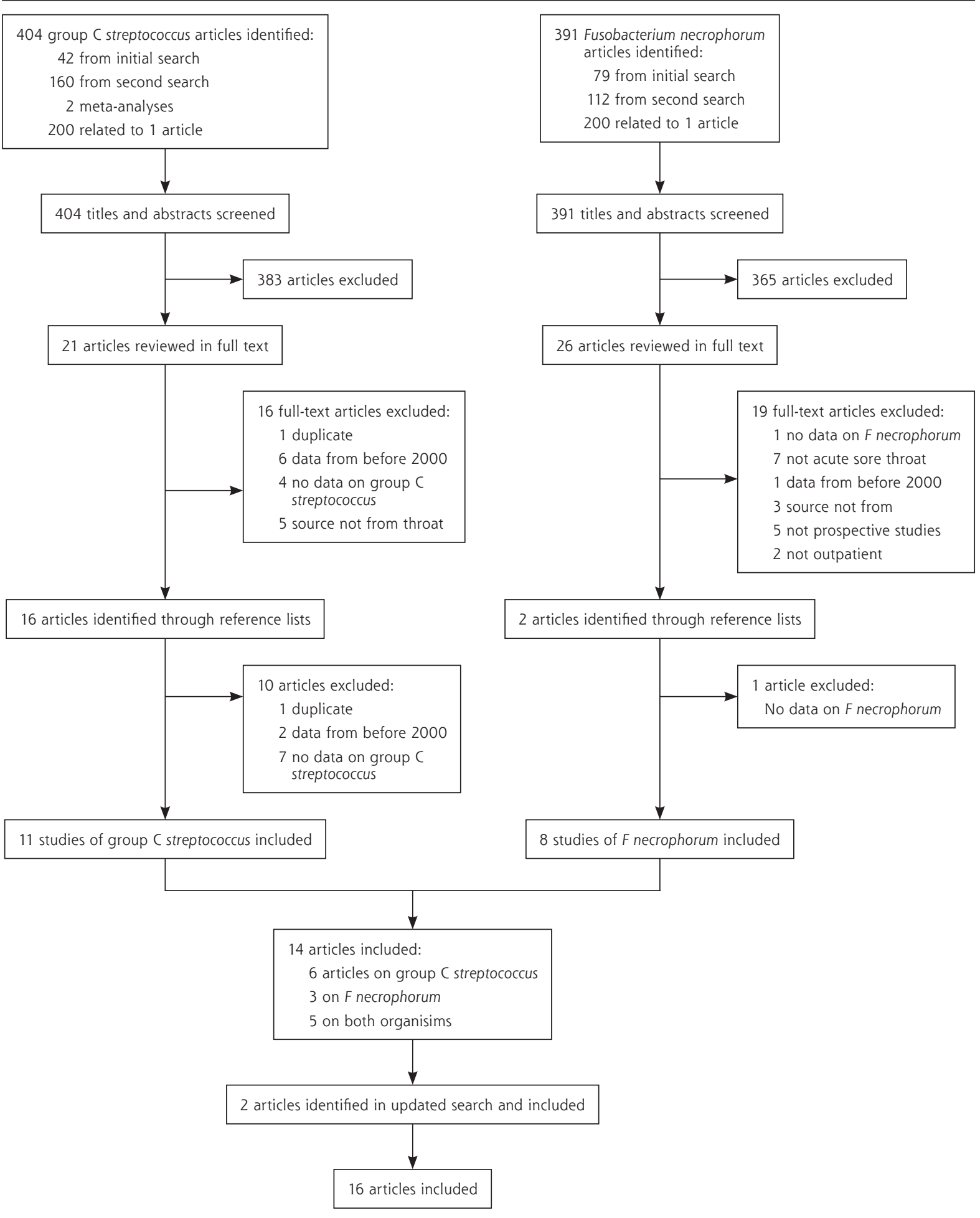


be a more common cause of pharyngitis than previously recognized, especially in younger adults.

Table 2 summarizes the clinical signs and symptoms of patients with pharyngitis associated with Group A streptococcus, Group C streptococcus, and F necropborum from 3 studies, 1 of which included F necropborum. ${ }^{4,5,7}$ The clinical presentations are very similar for patients with any of the 3 bacteria, again supporting the idea that they may be pathogenic.

The argument for detection and treatment is threefold. While Group C streptococcus is not a cause of rheumatic fever, this is an exceedingly rare complication of Group A streptococcus, and treatment solely for that purpose is not cost-effective. ${ }^{28}$ Treatment of all 3 infections, however, may reduce the duration of symptoms, decrease the likelihood of spread (particularly in communal living settings such as universities), and for $F$ necrophorum it has may prevent rare complications such as peritonsillar abscess and Lemierre's syndrome. It is premature, however, to recommend antibiotic treatment for these pathogens. The natural history of F necropborum and Group C streptococcus are currently poorly understood, and we agree with others that randomized trials of antibiotic treatment are needed. ${ }^{29}$

Table 1. Characteristics of Studies Reporting the Prevalence of Group C beta hemolytic Streptococcus and Fusobacterium necrophorum

\begin{tabular}{|c|c|c|c|c|c|}
\hline $\begin{array}{l}\text { Author, Year } \\
\text { (Country) }\end{array}$ & Population & Age & Setting $^{a}$ & $\begin{array}{l}\text { Years } \\
\text { of Data } \\
\text { Collection }\end{array}$ & $\begin{array}{l}\text { Diagnostic } \\
\text { Method }\end{array}$ \\
\hline \multicolumn{6}{|l|}{ Group C Streptococci } \\
\hline $\begin{array}{l}\text { Lindbaek et al, }{ }^{4} \\
2005 \text { (Norway) }\end{array}$ & $\begin{array}{l}\text { Adults and children with sore throat for }<7 \mathrm{~d} \\
\text { and no recent antibiotic presenting to GP. }\end{array}$ & $\begin{array}{c}\text { Mean } 23.9 \mathrm{y} ; \\
244 \text { adults, } \\
62 \text { children }<10 \text { y }\end{array}$ & Primary care & $2000-2002$ & Culture \\
\hline $\begin{array}{l}\text { Fretzayas et al, }{ }^{17} \\
2009 \text { (Greece) }\end{array}$ & $\begin{array}{l}\text { Children with pharyngitis and no recent anti- } \\
\text { biotics presenting to an outpatient clinic. }\end{array}$ & $\begin{array}{l}\text { Mean } 6.5 y, \\
\text { range } 4 y-14 y\end{array}$ & Primary care & 2006 & Culture \\
\hline $\begin{array}{l}\text { Little et al },_{1}^{5} 2012 \\
\quad \text { (England) }\end{array}$ & $\begin{array}{l}\text { Adults and children presenting to a GP with } \\
\text { sore throat for }<14 \mathrm{~d} \text { as the primary } \\
\text { symptom. }\end{array}$ & $\begin{array}{l}\geq 5 \text { yi } 11 \% \text { were } \\
5 y-9 y\end{array}$ & Primary care & $2007-2008$ & Culture \\
\hline $\begin{array}{l}\text { Cohen et al, }{ }^{18} 2012 \\
\text { (France) }\end{array}$ & $\begin{array}{l}\text { Children with pharyngitis and no recent anti- } \\
\text { biotics presenting to their pediatrician. }\end{array}$ & $\begin{array}{l}\text { Mean } 6.1 y \\
\text { range } 3 y-5 y\end{array}$ & Primary care & $2008-2010$ & Culture \\
\hline $\begin{array}{l}\text { Llor et al, }{ }^{19} 2009 \\
\quad \text { (Spain) }\end{array}$ & $\begin{array}{l}\text { Adults presenting to GP with acute pharyngitis } \\
\text { and } \geq 2 \text { Centor criteria. }\end{array}$ & $\begin{array}{l}\text { Mean } 30.6 \mathrm{y} \text {, } \\
\text { range } \geq 14 \mathrm{yr}\end{array}$ & Primary care & $2007-2008$ & Culture \\
\hline $\begin{array}{l}\text { Calvino et al, }{ }^{20} 2014 \\
\quad \text { (Spain) }\end{array}$ & $\begin{array}{l}\text { Adults presenting to an outpatient health cen- } \\
\text { ter with pharyngitis and all } 4 \text { Centor criteria. }\end{array}$ & $\begin{array}{l}\text { Mean } 28.5 y_{1} \\
\text { range } 18 y-51 y\end{array}$ & Primary care & 2010-2012 & Culture \\
\hline \multicolumn{6}{|c|}{ Fusobacterium necrophorum } \\
\hline $\begin{array}{l}\text { Ludlam et al, }{ }^{21} 2009 \\
\quad \text { (United Kingdom) }\end{array}$ & $\begin{array}{l}\text { Two groups: } 411 \text { students, of whom } 85 \text { had a } \\
\text { sore throat, and } 103 \text { patients presenting to } \\
\text { a GP with sore throat. }\end{array}$ & $\begin{array}{l}\text { University students: } \\
\text { median } 20 \mathrm{y} \\
\text { range } 18 \mathrm{y}-39 \mathrm{y} \\
\text { GP patients: median } \\
26 \mathrm{y} \text {, range } 2 \mathrm{y}-77 \mathrm{y}\end{array}$ & Primary care & 2005-2006 & PCR \\
\hline $\begin{array}{l}\text { Bank et al, }{ }^{16} 2010 \\
\text { (Denmark) }\end{array}$ & $\begin{array}{l}\text { All throat swabs submitted to a regional labora- } \\
\text { tory from primary care practice during } 2 \text { mo. }\end{array}$ & $\begin{array}{l}\text { Median } 20 y \text {, } \\
\text { range } 0 y-57 y\end{array}$ & $\begin{array}{l}\text { Laboratory- } \\
\text { based }\end{array}$ & 2009 & PCR \\
\hline $\begin{array}{l}\text { Bank et al, }{ }^{22} 2013 \\
\quad \text { (Denmark) }\end{array}$ & $\begin{array}{l}\text { All throat swabs submitted to a regional } \\
\text { laboratory from primary care practices for } \\
\text { patients age } 15 \text { y-24 y. }\end{array}$ & Range 15 y-24 y & $\begin{array}{l}\text { Laboratory- } \\
\text { based }\end{array}$ & 2007-2009 & Culture \\
\hline \multicolumn{6}{|l|}{ Both pathogens } \\
\hline $\begin{array}{l}\text { Aliyu et al, }{ }^{23} 2004 \\
\text { (United Kingdom) }\end{array}$ & $\begin{array}{l}\text { Random sample of } 100 \text { throat swabs submit- } \\
\text { ted by primary care physicians during } 7 \text { mo. }\end{array}$ & $\begin{array}{l}\text { Mean } 25 \text { y, } \\
\text { range } 5 \text { mo-79 y }\end{array}$ & $\begin{array}{l}\text { Laboratory- } \\
\text { based }\end{array}$ & 2003 & Culture \\
\hline $\begin{array}{l}\text { Batty et al, }{ }^{24} 2005 \\
\quad \text { (United Kingdom) }\end{array}$ & All throat swabs received during a 4 wk period. & $1 y-47 y$ & $\begin{array}{l}\text { Laboratory- } \\
\text { based }\end{array}$ & 2005 & Culture \\
\hline $\begin{array}{l}\text { Amess et al, }{ }^{10} 2007 \\
\quad \text { (United Kingdom) }\end{array}$ & All throat swabs received during 6 mo. & $<1 \mathrm{y}$ to $88 \mathrm{y}$ & $\begin{array}{l}\text { Laboratory- } \\
\text { based }\end{array}$ & 2004-2005 & Culture \\
\hline $\begin{array}{l}\text { Jensen et al, }{ }^{25} 2007 \\
\text { (Denmark) }\end{array}$ & $\begin{array}{l}\text { All throat swabs received during } 7 \text { mo from } \\
\text { patients with a diagnosis consistent with } \\
\text { tonsillitis or pharyngitis. }\end{array}$ & Range 18 y-32 y & $\begin{array}{l}\text { Laboratory- } \\
\text { based }\end{array}$ & $2005-2006$ & $P C R$ \\
\hline $\begin{array}{l}\text { Eaton et al, }{ }^{26} 2014 \\
\quad \text { (United Kingdom) }\end{array}$ & All throat swabs received during 1 y. & $\begin{array}{l}\text { Not reported; } \\
\text { largely } 10 y-49 \text { y }\end{array}$ & $\begin{array}{l}\text { Laboratory- } \\
\text { based }\end{array}$ & $2011-2012$ & Culture \\
\hline $\begin{array}{l}\text { Hedin et al, }{ }^{27} 2015 \\
\quad \text { (Sweden) }\end{array}$ & $\begin{array}{l}\text { Adults presenting to a GP with acute } \\
\text { pharyngo-tonsillitis. }\end{array}$ & $\begin{array}{l}\text { Median } 33 \text { y, } \\
\text { range } 15 y-48 y\end{array}$ & Primary care & $2011-2012$ & Culture \\
\hline $\begin{array}{l}\text { Centor et al, }{ }^{7} 2015 \\
\text { (United States) }\end{array}$ & $\begin{array}{l}\text { Adults with sore throat presenting to a college } \\
\text { health center. }\end{array}$ & $\begin{array}{l}\text { Mean } 22.3 y \\
\text { range } 15 y-30 y\end{array}$ & Primary care & $2013-2014$ & PCR \\
\hline
\end{tabular}




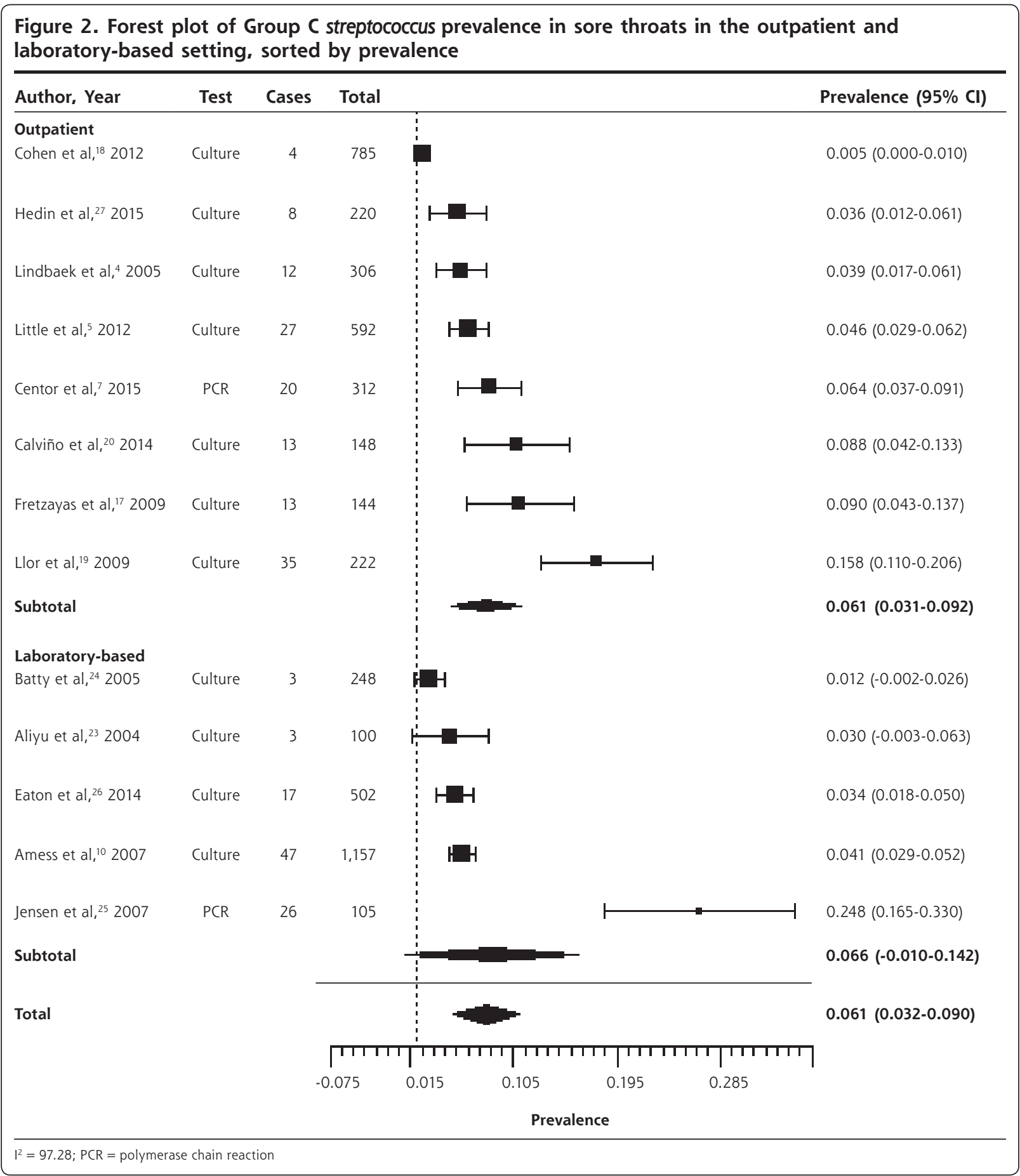

Centor argues that a randomized trial of antibiotics would be unethical in patients with $F$ necrophorum associated pharyngitis. ${ }^{7}$ We respectfully disagree, since the serious complication of Lemierre's syndrome is exceedingly rare. A college health population would be the ideal setting for such a trial, given the frequency of both bacteria in young adults with sore throat. One could obtain throat cultures in all patients presenting with sore throat, and randomize those with a Centor score of 2 or more and a negative rapid test for Group A streptococcus to antibiotic or placebo. The antibiotic or placebo could be discontinued for those with a negative culture for Group C streptococcus or F necrophorum, but continued for those with a positive culture for 1 of these pathogens.

Most of the included studies excluded patients who had received antibiotics before enrollment. Seven stud- 
ies did not mention including or excluding

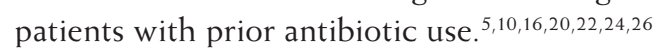
Of these 7, 5 were laboratory-based. It was because the laboratory-based studies did not indicate why swabs were submitted or provide details regarding previous antibiotics that we stratified our analysis by setting. The prevalence in laboratory-based studies was similar to that in outpatient primary care studies, however, suggesting that they were including similar patients.

Our analysis had several limitations. First, most of the studies of outpatients that we included, especially for $F$ necropborum, were in young adults and university health centers. The prevalence in other age groups is therefore less certain. Second, we found considerable unexplained heterogeneity, especially in
Table 2. Prevalence of Signs and Symptoms in Patients With Pharyngitis Associated With Group A streptococcus, Group C streptococcus, and Fusobacterium necrophorum

\begin{tabular}{|c|c|c|c|}
\hline \multirow[b]{2}{*}{ Symptom or Sign } & \multicolumn{3}{|c|}{$\begin{array}{l}\text { Percentage With this } \\
\text { Sign or Symptom }\end{array}$} \\
\hline & $\begin{array}{c}\text { Group A } \\
\text { streptococcus }\end{array}$ & $\begin{array}{c}\text { Group C } \\
\text { streptococcus }\end{array}$ & F necrophorum \\
\hline Cervical adenopathy ${ }^{4,5,7}$ & $71-91$ & $82-93$ & 66 \\
\hline Absence of cough ${ }^{4,5,7}$ & $67-90$ & $63-80$ & 62 \\
\hline Fever ${ }^{4,5,7}$ & $29-80$ & $47-76$ & 38 \\
\hline Tonsillar exudates ${ }^{4,5,7}$ & $25-52$ & $24-56$ & 34 \\
\hline Redness in pharynx ${ }^{4}$ & 88 & 79 & NT \\
\hline Pain on swallowing ${ }^{4}$ & 57 & 36 & NT \\
\hline Duration $\leq 3 d^{5}$ & 70 & 64 & NT \\
\hline Severely inflamed tonsils ${ }^{5}$ & 30 & 38 & NT \\
\hline Absence of runny nose ${ }^{5}$ & 71 & 76 & NT \\
\hline
\end{tabular}

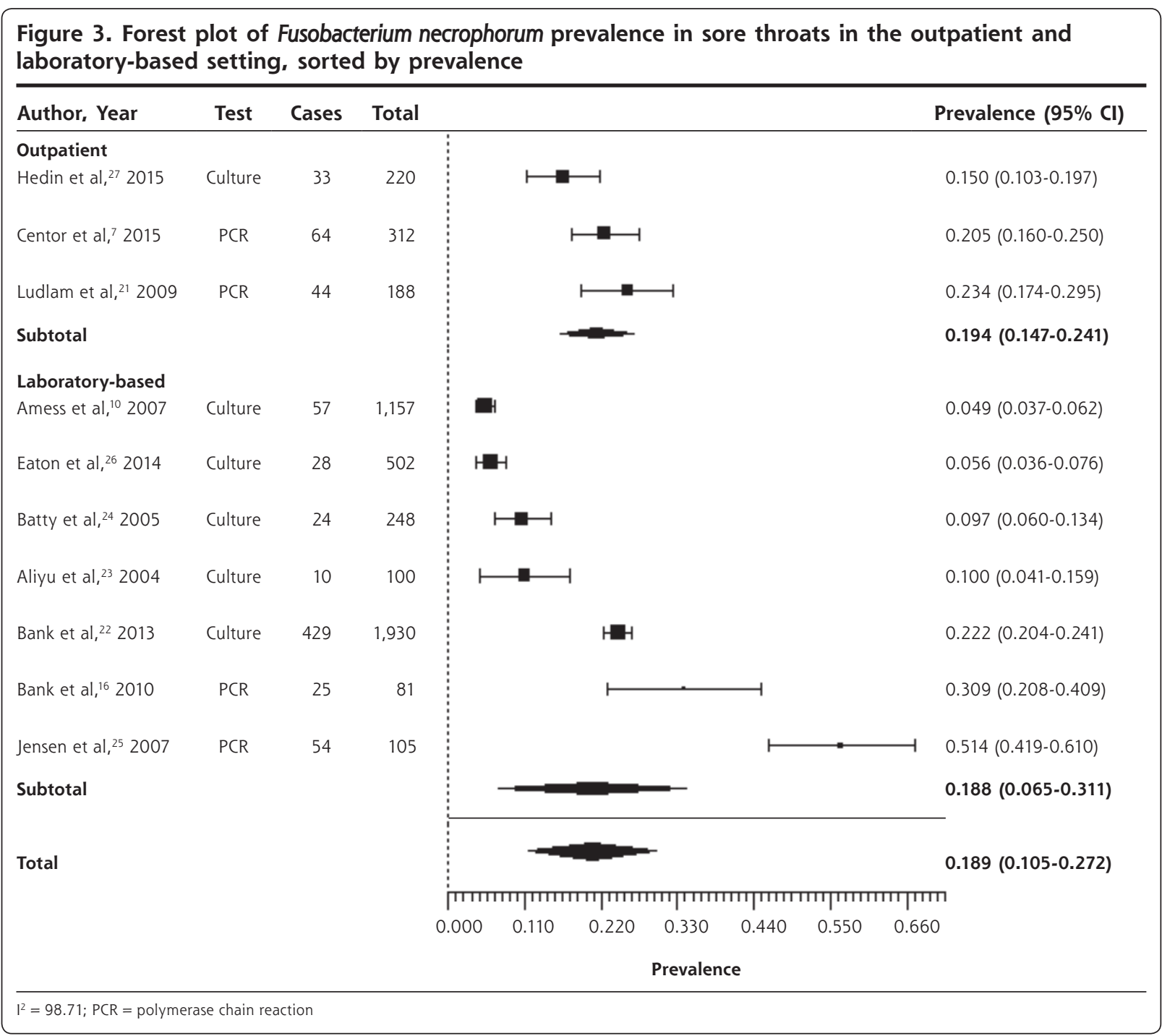


the laboratory-based studies of $F$ necrophorum. This may be due to differences in laboratory techniques or the gathering of samples, in study populations, or in other unrecognized factors. Furthermore, PCR is an evolving technology for the detection of Fusobacterium, and the sensitivity may vary based on the specific sequences used and may be falsely elevated due to contamination with other samples. Last, our search was limited to the only database available to us, MEDLINE; the inclusion of other databases may reveal additional studies not included in this analysis.

In summary, our systematic review confirms that both Group C streptococcus and F necrophorum are commonly found in patients with acute pharyngitis, especially in young adult populations, and further study (including randomized controlled trials of treatment) is needed to determine whether treatment is beneficial.

\section{To read or post commentaries in response to this article, see it} online at http://www.annfammed.org/content/14/6/567.

Key words: pharyngitis, Group C streptococcus prevalence, Fusobacterium necrophorum prevalence, primary care

Submitted February 5, 2016; submitted, revised, June 3, 2016; accepted July 13, 2016.

Supplementary materials: Available at http://www.AnnFamMed. org/content/14/6/567/suppl/DC1/.

\section{References}

1. Centers for Disease Control and Prevention (CDC). National Ambulatory Medical Care Survey: 2012 State and National Summary Tables. 2015 November 6 [cited 2015 August 27]. http://www.cdc. gov/nchs/data/ahcd/namcs_summary/2012_namcs_web_tables.pdf.

2. Ebell MH, Smith MA, Barry HC, Ives K, Carey M. The rational clinical examination. Does this patient have strep throat? JAMA. 2000; 284(22):2912-2918.

3. Tiemstra J, Miranda RL. Role of non-group a streptococci in acute pharyngitis. J Am Board Fam Med. 2009;22(6):663-669.

4. Lindbaek M, Høiby EA, Lermark G, Steinsholt IM, Hjortdahl P. Clinical symptoms and signs in sore throat patients with large colony variant beta-haemolytic streptococci groups $C$ or $G$ versus group $A$. Br J Gen Pract. 2005;55(517):615-619.

5. Little P, Hobbs FD, Mant D, McNulty CA, Mullee M. Incidence and clinical variables associated with streptococcal throat infections: a prospective diagnostic cohort study. Br J Gen Pract. 2012;62(604):e787-e794.

6. Efstratiou A. Pyogenic streptococci of Lancefield groups $C$ and $G$ as pathogens in man. Soc Appl Bacteriol Symp Ser. 1997;26:72S-79S.

7. Centor RM, Atkinson TP, Ratliff AE, et al. The clinical presentation of Fusobacterium-positive and streptococcal-positive pharyngitis in a university health clinic: a cross-sectional study. Ann Intern Med. 2015;162(4):241-247.

8. Kuppalli K, Livorsi D, Talati NJ, Osborn M. Lemierres syndrome due to Fusobacterium necrophorum. Lancet Infect Dis. 2012;12(10): 808-815.

9. Organisation for Economic Co-operation and Development (OECD). List of high income OECD countries and high income Euro area countries. In: Country Classification 2011 - as of 26 July 2011. https:// www.oecd.org/tad/xcred/48405330.pdf. Accessed Oct 31, 2016.
10. Amess JA, ONeill W, Giollariabhaigh CN, Dytrych JK. A six-month audit of the isolation of Fusobacterium necrophorum from patients with sore throat in a district general hospital. $\mathrm{Br} J$ Biomed Sci. 2007;64(2):63-65.

11. Whiting PF, Rutjes AW, Westwood ME, et al. QUADAS-2: a revised tool for the quality assessment of diagnostic accuracy studies. Ann Intern Med. 2011;155(8):529-536.

12. Higgins J, Altman D, Sterne J. Cochrane handbook chapter 8: Assessing risk of bias in included studies. In: Higgins J, Green S, eds. Cochrane Handbook for Systematic Reviews of Interventions. Version 5.1.0. http://handbook.cochrane.org/chapter_8/8_assessing_risk_of_ bias_in_included_studies.htm. Updated Mar 2011. Accessed 2015.

13. Barendregt JJ, Doi SA, Lee YY, Norman RE, Vos T. Meta-analysis of prevalence. J Epidemiol Community Health. 2013;67(11):974-978.

14. Higgins JP, Thompson SG. Quantifying heterogeneity in a metaanalysis. Stat Med. 2002;21(11):1539-1558.

15. von Hippel PT. The heterogeneity statistic I(2) can be biased in small meta-analyses. BMC Med Res Methodol. 2015;15:35.

16. Bank S, Nielsen HM, Mathiasen BH, Leth DC, Kristensen LH, Prag J. Fusobacterium necrophorum- detection and identification on a selective agar. APMIS. 2010;118(12):994-999.

17. Fretzayas A, Moustaki M, Kitsiou S, Nychtari G, Nicolaidou P. The clinical pattern of group ( streptococcal pharyngitis in children. J Infect Chemother. 2009;15(4):228-232.

18. Cohen JF, Chalumeau M, Levy C, et al. Spectrum and inoculum size effect of a rapid antigen detection test for group A streptococcus in children with pharyngitis. PLoS One. 2012;7(6):e39085.

19. Llor C, Calviño O, Hernández $S$, et al. Repetition of the rapid antigen test in initially negative supposed streptococcal pharyngitis is not necessary in adults. Int J Clin Pract. 2009;63(9):1340-1344.

20. Calviño O, Llor C, Gómez F, González E, Sarvisé C, Hernández S. Association between $C$-reactive protein rapid test and group A streptococcus infection in acute pharyngitis. J Am Board Fam Med. 2014; 27(3):424-426.

21. Ludlam H, Howard J, Kingston B, et al. Epidemiology of pharyngeal carriage of Fusobacterium necrophorum. J Med Microbiol. 2009;58(Pt 9):1264-1265.

22. Bank S, Christensen K, Kristensen LH, Prag J. A cost-effectiveness analysis of identifying Fusobacterium necrophorum in throat swabs followed by antibiotic treatment to reduce the incidence of Lemierres syndrome and peritonsillar abscesses. Eur J Clin Microbiol Infect Dis. 2013;32(1):71-78.

23. Aliyu SH, Marriott RK, Curran MD, et al. Real-time PCR investigation into the importance of Fusobacterium necrophorum as a cause of acute pharyngitis in general practice. J Med Microbiol. 2004;53(Pt 10):1029-1035.

24. Batty A, Wren MW. Prevalence of Fusobacterium necrophorum and other upper respiratory tract pathogens isolated from throat swabs. Br J Biomed Sci. 2005;62(2):66-70.

25. Jensen A, Hagelskjaer Kristensen L, Prag J. Detection of Fusobacterium necrophorum subsp. funduliforme in tonsillitis in young adults by real-time PCR. Clin Microbiol Infect. 2007;13(7):695-701.

26. Eaton C, Swindells J. The significance and epidemiology of Fusobacterium necrophorum in sore throats. J Infect. 2014;69(2):194-196.

27. Hedin K, Bieber L, Lindh M, Sundqvist M. The aetiology of pharyngotonsillitis in adolescents and adults - Fusobacterium necrophorum is commonly found. Clin Microbiol Infect. 2015;21(3):263.e1-7.

28. National Institute for Health and Care Excellence. NICE guidelines: respiratory tract infections (self-limiting): prescribing antibiotics. https://www.nice.org.uk/guidance/cg69. Published Jul 2008. Accessed Dec 30, 2015.

29. Uhl JR, Gustafson DR, Rucinski SL, Patel R. FusobacteriumPositive and Streptococcal-Positive Pharyngitis. Ann Intern Med. 2015;162(12):876-877. 